\title{
Issues in the Establishment of Asset Management Companies
}

\author{
Stefan Ingves, Steven A. Seelig, \\ and Dong $\mathrm{He}$
}




\title{
IMF Policy Discussion Paper
}

Monetary and Financial Systems Department

\section{Issues in the Establishment of Asset Management Companies}

Prepared by Stefan Ingves, Steven A. Seelig, and Dong He

May 2004

\begin{abstract}
This Policy Discussion Paper should not be reported as representing the views of the IMF. The views expressed in this Policy Discussion Paper are those of the author(s) and do not necessarily represent those of the IMF or IMF policy. Policy Discussion Papers describe research in progress by the author(s) and are published to elicit comments and to further debate.
\end{abstract}

This paper discusses the role of asset management companies (AMCs) in facilitating bank restructuring and specifies some policy lessons learned from international experience. The paper concludes that there is no single optimal solution but a combination of strategies that will vary from bank to bank and country to country. There are, however, common factors that contribute to the success of an AMC and these include the legal environment, leadership, independence, incentives, and commercial orientation.

JEL Classification Numbers: G28 and G33

Keywords: bank restructuring, asset management, corporate restructuring, loan restructuring Author’s E-Mail Address: SIngves@imf.org; SSeelig@imf.org; and DHe@imf.org 


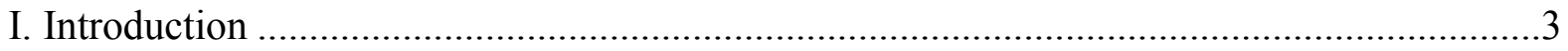

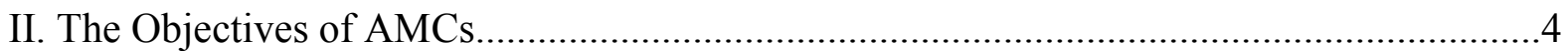

A. Asset Management and Bank Restructuring .......................................................

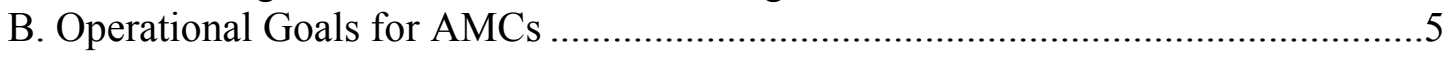

III. Structural and Organizational Issues ......................................................................

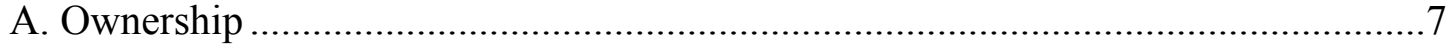

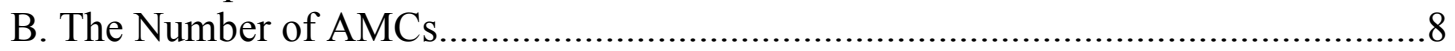

C. Legal Powers of AMCs ..................................................................................... 11

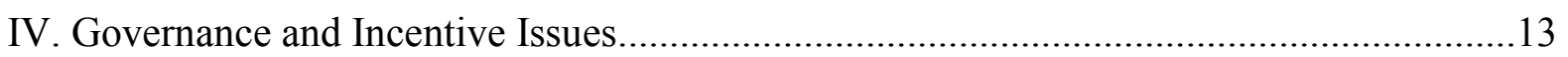

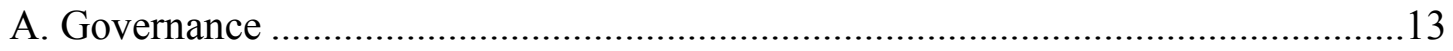

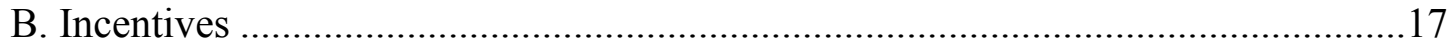

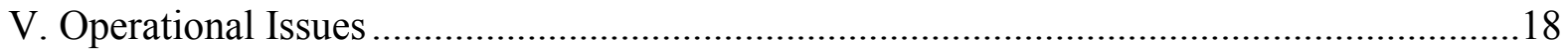

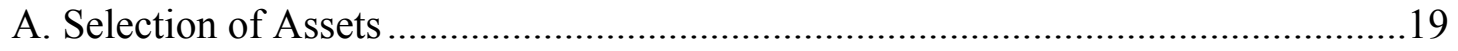

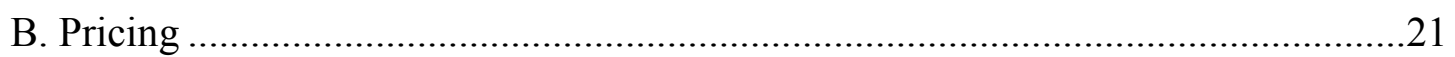

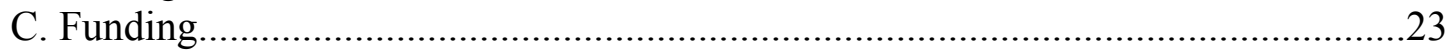

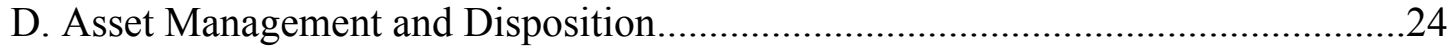

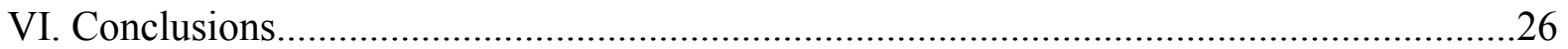

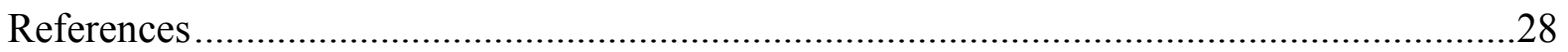

Text Table

1. Considerations for Decentralized Asset Management …......................................10

Box

1. Advantages and Disadvantages of a Centralized Public AMC ................................... 


\section{INTRODUCTION}

This paper discusses the role of asset management companies in facilitating bank restructuring and derives some lessons from recent experiences. It reviews various options and cross-country experiences in dealing with impaired assets during periods of financial crises. It argues that there are alternative strategies for managing and disposing of impaired assets, depending on factors such as the type of asset, size and distribution, the structure of the banking system, and available management capacity in the banks and in the public sector. The paper concludes that there is no single optimal solution but rather a combination of solutions for each country that may vary over time and for each bank resolution. There are, however, common factors that contribute to the success of AMCs. These include supporting legal and regulatory environment, strong leadership, operational independence, appropriately structured incentives, and commercial orientation.

The paper is organized as follows: Section II discusses the objectives of AMCs in the context of a systemic bank restructuring strategy. Section III discusses the pros and cons of different approaches to the structure and organization of AMCs, and analyzes the factors that should be considered in choosing the right structure. Section IV discusses governance and incentive structure issues in different types of AMCs. Section V discusses the operational issues of AMCs, and Section VI provides some concluding remarks. 


\section{THE OBJECTIVES OF AMCS}

\section{A. Asset Management and Bank Restructuring}

Proper management and disposition of nonperforming assets is one of the most critical and complex aspects of financial sector crisis management. Successful bank restructuring entails preserving the payment system, assuring that there are functioning banks, and that the residual troubled assets are managed and disposed of appropriately. While loan workouts are part and parcel of normal banking business, if the size of bad assets reaches systemic proportions, there are a number of reasons why setting up separate AMCs becomes necessary, not the least of which is to assure that corporate restructuring occurs. When AMCs hold a large percentage of financial sector assets, corporate workouts and restructuring should become a key part of their mission.

Probably the most important purpose of having AMCs is the managerial factor. The handling of bad loans and assets require other skills than are normally available in a bank. Real estate specialists, liquidation experts, and people with insights into various industrial sectors may be needed. In addition, managing the bad assets would interfere with the daily running of the bank. Importantly, both the good bank and the AMC could be given independent and transparent profit goals if separated. That would provide incentives for managers and staff.

Country experiences show that AMCs have been set up for a number of reasons. These include the facilitation of (a) the resolution of insolvent and nonviable financial institutions; (b) the restructuring of distressed but viable financial institutions; and (c) the privatization of government-owned and government-intervened banks. Examples of (a) include the 
Resolution Trust Corporation (RTC) in the United States and the Thai Financial Sector Restructuring Agency (FRA). Examples of (b) include the Swedish Securum and Cinda Asset Management Company in China. The mandates of the Korea Asset Management Corporation (KAMCO) and the Malaysian Danaharta encompassed both (a) and (b). Examples of (c) include the French Consortium de Realization, which was created as a subsidiary of Credit Lyonnais in 1995 to take over nonperforming assets from the bank before its privatization in 1999, and the AMC owned by the Financial Institutions Development Fund in Thailand for the sale of Radanasin Bank. The Indonesian Bank Restructuring Agency (IBRA) combined all three elements.

\section{B. Operational Goals for AMCs}

For an AMC to operate effectively it is imperative that it have clearly defined goals and a governance structure that is both supportive of these goals and assures that management meets the goals. Different countries have taken different approaches to defining the goals for their AMCs. ${ }^{1}$ AMCs in different countries may have different focuses. In some countries the AMCs operated with a focus on disposing of the assets acquired/transferred to the government. These AMCs functioned as rapid disposition vehicles quickly selling assets to the private sector. In all cases the goal was to dispose of the asset as quickly as possible so as to avoid further deterioration in value and to minimize the carrying cost of the government. It should be recognized that rapid disposition requires the AMC to have good information about the assets it is attempting to dispose of and that a market for these assets exists.

\footnotetext{
${ }^{1}$ See Klingebiel (2000) for a listing of objectives for AMCs in different countries.
} 
Countries such as Korea and the United States in the case of the Federal Deposit Insurance Corporation (FDIC) signaled the market of the seriousness of their intent by initially conducting small sales and completing them successfully.

In other countries the government set up vehicles whose focus was on restructuring. In some cases, the emphasis was on restructuring the nonperforming loans (NPLs) so as to make them marketable. In others, the goal was to achieve broader corporate restructuring of the borrowers and the government-owned banks.

Regardless the focuses of different AMCs, their operations should be guided ultimately by the objective of profit maximization or loss minimization, taking into full account market conditions as well as the funding cost to the AMC. Experience has shown that AMCs with clearly defined, focused, and consistent goals are more likely to be effective. In some instances, such as the United States, social objectives were added to the asset management objectives of the AMC. The RTC was required to promote social goals in the areas of affordable housing and historic preservation by developing programs and giving preference to buyers who would meet program goals. The practice of mixing goals, and especially establishing conflicting objectives, is not recommended. Fortunately in the case of the RTC, the vast majority of the assets were not subject to social objectives and it was able to pursue its rapid sale strategies with success. 


\section{StruCtural AND ORganizational ISSUES}

\section{A. Ownership}

Various approaches to the structure and organization of AMCs can be adopted to achieve the authorities' objectives. In terms of ownership, AMCs can be either public or private and within these there are alternative structures. Similarly, the sellers of assets to the AMC can be private or public entities. When a substantial amount of bad loans and assets has to be transferred to an AMC over a short period of time, it is often difficult to find a private investor willing to own such an AMC without asking for far-reaching government guarantees covering the future value of the asset portfolio. In this situation, the government is in a more favorable position owning the AMC itself rather than providing guarantees, since it might then benefit from any future upward price movements of the AMC's assets. In addition, it is difficult to formulate guarantees that would give a private owner strong incentives to sell the assets at the best prices. This could lead to further losses for the state.

When a single bank has a medium to large amount of bad loans and assets, an option is to set up an AMC as a subsidiary of the same bank. In doing so, the bank would benefit from its knowledge and close contacts with borrowers. However, it is important to guard against the AMC becoming the focus of the bank's management who should be working on restructuring the "cleaned-up" bank. In addition, certain types of assets, such as real estate, may be better handled by nonbank professionals. If the government has provided financial support to the bank, it may ask for a share in the "upside" of the AMC subsidiary. 
Public AMCs can be freestanding entities or may be a responsibility of an existing public agency, such as the ministry of finance or the deposit insurer. It is preferable, however, that AMCs not be set up as a unit within the central bank, or as its subsidiary, since the central bank's primary responsibility is to achieve and maintain price stability, and its balance sheet should not be made unwieldy by taking on large amounts of nonperforming assets of the banking system.

\section{B. The Number of AMCs}

Although there are no clear-cut rules as to the superiority of having a single AMC monopoly (the centralized approach) versus having a number of competing AMCs (the decentralized approach), there are advantages and disadvantages associated with each of them (Box 1 and Table 1). A very large AMC may obtain economies of scale but could also become unwieldy, which might hamper the ability to react swiftly, such as in sales transactions. In addition, problem loans and assets require far more work than a similar number of performing loans. In general, the choice of a particular organizational structure for AMCs depends on a number of factors, including types of assets, magnitude of the problem, depth of markets, and characteristics of debtors. For instance, when the types of impaired assets in different banks

differ substantially, there may be some rationale to group assets by types and to transfer them to AMCs specializing in the management of a particular type or types of assets. When there is lack of depth in markets for certain assets, there may be stronger rationale for a centralized approach in the disposition of such assets. 
Box. 1. Advantages and Disadvantages of a Centralized Public AMC

\section{Advantages}

- Serves as a vehicle for getting NPLs out of troubled banks, based on uniform valuation criteria.

- Allows government to attach conditions to purchases of NPLs in terms of bank restructuring.

- Centralizes scarce human resources (domestic and foreign).

- Centralizes ownership of collateral, thus providing more leverage over debtors and more effective management.

- Can better force operational restructuring of troubled banks.

- Can be given special legal powers to expedite loan recovery and bank restructuring.

\section{Disadvantages}

- Management is often weaker than in private structures, reducing the efficiency and effectiveness of its operations.

- Such agencies are often subject to political pressure.

- Values of acquired assets erode faster when they are outside a banking structure.

- NPLs and collateral are often long-term "parked" in an AMC, not liquidated.

- If not actively managed, existence of public AMC could lead to a general deterioration of credit discipline in financial system.

- Cost involved in operating an AMC may be higher than a private arrangement.

- If dealing with private banks, determining transfer prices is difficult. 
Table 1. Considerations for Decentralized Asset Management

\begin{tabular}{|c|c|c|}
\hline & Within Banks & In Private AMCs \\
\hline \multirow[t]{4}{*}{ Advantages } & \multirow{2}{*}{$\begin{array}{l}\text { Knowledge of the borrower may facilitate } \\
\text { debt restructuring. }\end{array}$} & Specialized skill mix. \\
\hline & & Focus on restructuring function. \\
\hline & $\begin{array}{l}\text { Access to borrower through branch } \\
\text { network. }\end{array}$ & $\begin{array}{l}\text { Creation of an asset management industry } \\
\text { and secondary market for distressed } \\
\text { assets. }\end{array}$ \\
\hline & & $\begin{array}{l}\text { Up-front loss recognition. Cleans up the } \\
\text { bank's books. }\end{array}$ \\
\hline \multirow[t]{5}{*}{ Disadvantages } & Lack of skills for restructuring of troubled & Lack of knowledge of the borrower. \\
\hline & $\begin{array}{l}\text { debt, operations of companies, debt- } \\
\text { equity swaps, etc. }\end{array}$ & \multirow{4}{*}{$\begin{array}{l}\text { Bank may not have sufficient capital to } \\
\text { recognize up-front losses associated with } \\
\text { selling to an AMC. }\end{array}$} \\
\hline & $\begin{array}{l}\text { Hampers "normal" banking functions } \\
\text { (lending activities), particularly if the } \\
\text { NPL portfolio is large. }\end{array}$ & \\
\hline & $\begin{array}{l}\text { Less up-front loss recognition. Does not } \\
\text { clean up the bank's books. }\end{array}$ & \\
\hline & $\begin{array}{l}\text { May be problems of conflicts of interest } \\
\text { with the parent bank as well as } \\
\text { governance issues. }\end{array}$ & \\
\hline
\end{tabular}

During the Asia financial crises, each country considered the advantages and disadvantages of dealing with impaired assets in a centralized or decentralized AMC structure and related ownership issues in the context of its own circumstances. Centralized AMCs, which typically are state owned, have been used in Indonesia, Korea, and Malaysia. This does not exclude privately owned banks from setting up their own AMCs. For example, in Thailand a more mixed approach was used. While encouraging each commercial bank to establish its own separate AMC, a public AMC was established to purchase residual assets from the FRA. ${ }^{2}$ In

${ }^{2}$ Subsequent to the crisis, a government-owned centralized AMC, the Thai Asset Management Corporation, was set up in 2001 to purchase NPLs from open banks. 
Indonesia private $\mathrm{AMCs}$ to deal with failed banks were ruled out due to governance concerns. $^{3}$

\section{Legal Powers of AMCs}

An important issue in setting up AMCs concerns their legal powers. The legal basis of the AMC should provide for clean transfers of titles (and the associated priority) in all asset transactions of the AMC. Similarly, legal obstacles for the transfer of assets, such as the requirement that the permission of the debtors be obtained before the transfer of loans can be effected, should be removed. The legal basis should ensure that the AMC "stands in the shoes" of the former bank at least in the eyes of the law. In addition, asset disposition by public AMCs could be retarded by perceived potential legal liabilities accruing to the AMC management. ${ }^{4}$ In this situation, legal protection for the employees of the AMCs in the execution of their responsibilities in good faith should be considered.

A legal system that includes an orderly and effective insolvency process is where bank and corporate restructuring meet. An effective insolvency system with well-designed vehicles for rehabilitation and liquidation can lead to an efficient maximization of resources in both the banking and the corporate sectors, and the economy as a whole. In this environment, efforts should be made to coordinate the design and implementation of bank and corporate restructuring strategies so that they do not work at cross purposes. For example, if the goal of

\footnotetext{
${ }^{3}$ This was done to prevent associates of some of the failed banks from setting up private AMCs, which could have circumvented rules for pricing and prudent governance.

${ }^{4}$ They could be personally sued by borrowers or potential purchasers who are unhappy with the decisions of the AMC and wish to apply pressure to management.
} 
corporate restructuring is to maintain viable companies, then the strategy of the AMC should not be rapid conversion to cash but rather focus on corporate workouts and possible equity ownership positions.

Another issue is whether special legal powers are needed for the AMC to facilitate the recovery process. Effective asset management and disposition requires the support of an effective legal system. Such a system should clearly define the rights of ownership as well as the legal obligations between debtors and creditors and provide for the orderly resolution of disputed claims, including debt recovery and realization of collateral for unpaid debt. Such a system should also balance the protection of creditors and that of debtors. However, when the existing legal system is not equipped to deal with the magnitude of the nonperforming assets (e.g., when the court system is inexperienced and does not have enough resources), or when endeavors to reform the system are excessively time-consuming, there may be a case to grant special legal powers to AMCs to facilitate asset recovery and restructuring. In Malaysia, for example, Danaharta is able to make use of three such powers: (i) special vesting powers insulate Danaharta and subsequent purchasers from undisclosed claims made after Danaharta acquires the NPL from the selling bank; (ii) Danaharta is able to appoint special administrators without having to go to court; and (iii) Danaharta can readily foreclose on collateral. The drawbacks of this approach, including potential abuse of these special powers and further weakening of legal due processes, should be carefully examined when considering granting such powers to AMCs. 


\section{GOVERNANCE AND INCENTIVE ISSUES}

\section{A. Governance}

As with any type of organization, good governance is necessary to assure the effective operation of an AMC. Especially in the case of a government-owned AMC, governance issues are critical because the $\mathrm{AMC}$ is, on the one hand, subject to potential political pressure and, on the other, is accountable to the public for its actions and performance. Therefore, it is essential that an AMC be both independent and transparent with regard to its operations. Its stakeholders - the public, government, and shareholders - must be able to evaluate its performance.

Because AMCs handle large volumes of assets, and in some countries may control a significant percentage of the wealth of the nation, it is important that they be insulated from political interference in the disposition and restructuring of assets. The very nature of the asset management process invites political interference. If delinquent borrowers feel they may get more favorable treatment by contacting their elected officials, it is likely that they will do so. One must also expect elected representatives to make inquiries on behalf of their constituents. The critical balance is to assure that the AMC does not take inappropriate actions as a result of pressure, but at the same time is responsive to the public.

Because it is likely to be subject to political pressure, steps should be taken to shelter the $\mathrm{AMC}$ from this pressure. One approach is to establish the AMC as an independent entity. Part of this protection is to give it independence from the budget appropriations process in 
the same manner as that of central banks. Rather, the AMC should fund its operating expenses from within its own balance sheet.

The structure of the AMC within the government is also an important issue. The closer the $\mathrm{AMC}$ is to being a regular executive branch entity, the more it is subject to political pressure and the more difficult it becomes to be creative with compensation incentives. The goal should be to make the AMC distinct from a typical government agency and to distance it from normal government operations. One approach that worked well in Sweden is to create a holding company type of structure with different layers of governance and possibly multiple AMCs focusing on distinct asset types. This structure provides greater flexibility in managing the assets, creates competitive incentives, and provides greater political insulation.

Along with independence, however, comes transparency and accountability. Transparency with respect to all of its operations and its performance is critical for the AMC's political independence. It is also key to maintaining public confidence that the liquidation process is being carried out in a fair and objective fashion. Transparency promotes accountability of the managers and the board vis-à-vis the public and reduces the perception of, and possibly tendencies for, corruption.

To assure transparency, AMCs should be required to publish regular reports describing their performance in pursuing their goals. The financial statements should be prepared in accordance with accepted liquidation and fund accounting practices. In addition, to making detailed financial information public, the AMCs should be audited regularly to assure that their financial statements are accurate, that representations as to the value of assets are 
reasonable, and that the $\mathrm{AMC}$ has proper internal controls in place to safeguard the assets under its management. Independent auditors chosen by the government should undertake such audits.

To help strengthen the independence of a government-owned AMC, it should be governed by a Board of Directors and, following principles of corporate governance, the majority should be outside independent directors. These directors should be sufficiently independent so as to be able to assist the AMC in resisting pressure from borrowers and prospective purchasers of assets seeking preferential treatment. The board should have a clearly defined mandate and it should be responsible for assuring that the AMC carries out its mission and meets performance goals. The board should have the flexibility to establish all policies and procedures for the AMC. These include policies for staff compensation, asset disposition strategies, credit and restructuring, budgets, and financial reporting.

Since asset management often involves contentious transactions, it is imperative that the governance structure of AMCs not be so limiting that the AMC loses its ability to deal with unforeseen circumstances. Experience has shown that managerial flexibility is extremely important to the effectiveness of AMCs.

A critical factor in assuring an AMC's success and independence is the ability of its stakeholders to evaluate its performance. This requires proper accounting for the assets at the time of transfer and for cash flows over time. Unfortunately, when AMCs have carried assets at their old book value, they typically show low recoveries leading the public to believe that the AMC has been a failure. Performance should be measured against either a "mark-to- 
market" value or an estimated recovery value at the time of transfer. If assets transfer at book value then appropriate provisions should be established as soon as possible after transfer, so that the initial shortfall is clear to everyone and performance is measured against original book value net of provisions.

In situations where privately owned and decentralized AMCs are used, there are also governance issues that must be addressed. If the government has ownership of the assets, or retains a significant financial exposure to the performance of the assets, it must assume regulatory oversight responsibility for the AMC. The challenge is for the government to assure itself that the assets are being managed and disposed of in an appropriate manner consistent with stated objectives, while at the same time not imposing an inefficient and overly burdensome oversight process. There are four key components to this process: (1) The agreements with the AMCs should clearly spell out the objectives, measurable performance requirements, and the delegations of authority from the government to the AMC; (2) AMCs should be required to prepare detailed reports on their actions and performance and provide all needed financial data to the government; (3) the government should audit the records and reports of the $\mathrm{AMC}$ and assure the same level of transparency as would be required of a public AMC; and (4) if the government has retained authority over certain actions, it must provide staff with appropriate authority to act quickly to approve or deny actions. These staff can also be the liaisons with the government agency having public accountability for the performance of the AMC. Variations on these approaches were used in the United States with great success. 


\section{B. Incentives}

AMCs face an inherent incentive problem. Most commercial operations assure their continued existence by being successful. However, asset management operations are in the business of going out of business. If they are successful, they will liquidate the assets under their management through restructuring and disposition and cease to exist. Consequently, it is important to design AMCs so that they do not become "warehouses" of NPLs. There is a need for a structure of incentives that are designed to ensure effective and efficient asset management and disposition. These incentives need to address both the issues of the limited life of the entity and the performance of the staff.

One approach to the problem of the AMC being a self liquidating entity is to develop incentives for the board members so that they will counterbalance the motivations of the staff to prolong the life of the AMC unnecessarily. These incentives can take the form of political rewards, such as higher office or public recognition of a job well-done or financial incentives to the directors. Another option that has been successful in several countries is to limit the life of the AMC at the time it is created. This approach worked well, and contributed to the success of the RTC and some of the private AMCs established by acquiring banks to manage assets for the FDIC. If the AMC is a public entity it helps to have senior career managers but rely on employees on term appointments, with terms that are tied to the expected life of the work. The use of term employees helps to alleviate political pressure to keep the AMC going in order to protect the jobs of its employees. 
The other critical incentive issue is how to motivate employees and managers to maximize outcomes consistent with goals. As contrasted to many types of governmental activity, the work of an AMC is essentially commercial. Consequently, it is essential that the AMC be able to attract and retain employees with appropriate skills and motivate them to maximize recoveries on impaired assets as quickly as possible. One option is to have two components in the compensation package: salary and performance-based bonuses. It should be recognized that governments might have to pay salaries higher than those paid to civil servants in order to attract individuals with the necessary skills. Because these jobs are of limited duration, paying a premium over the civil service pay scale should be defensible. In addition, bonuses are a powerful tool to encourage both recovery maximization and speedy recoveries. A risk is that assets will be disposed of regardless of price just so employees can get a quick bonus. However, this can be mitigated by having proper approval procedures and establishing appropriate goals for individual assets. Just as an AMC's performance should be judged based on its recoveries compared to the original estimated recovery value, a similar approach should be used for establishing performance goals for employees and managers.

\section{Operational IsSues}

Even though AMCs in different countries may have different organizational structures, a common factor that is critical to satisfactory performance is the commercial orientation of AMC's operations. Commercial orientation, in turn, depends critically on policies regarding selection of assets to be purchased or transferred, pricing of such assets, funding, and strategies for asset recovery. 


\section{A. Selection of Assets}

One of the first operational questions an AMC faces is whether it should buy assets from all banks, and what types of assets to buy from those banks. The ownership of the assets and the banks is often the key element in the decision. Some countries have chosen to acquire and sell assets only from banks that are being resolved by liquidation or merger, and hence under the ownership or control of the government. This was the case in Thailand ${ }^{5}$ and the United States. Other countries also provide assistance to banks that are to remain open by buying their bad assets. For example, Indonesia, Korea, Malaysia, and Mexico have bought bad assets from open banks. When the government "owns" the selling bank and the AMC, the transaction is straight forward. Similarly, a private bank selling assets to an independent private AMC is involved in an arm's-length transaction that should be devoid of conflicts. The issue becomes more difficult when the transactions are between private banks and public AMCs.

When a public AMC purchases assets from open banks, a potential conflict arises between economizing limited resources and being fair to all banks. Buying bad assets only from troubled banks that are to receive government assistance could prejudice the competitiveness of those better banks that are still struggling unaided to handle their portfolio of bad loans. One way for the government to resolve this dilemma is to buy some, but not all, of the bad assets of assisted banks. The assisted banks should be left with roughly the same proportion

\footnotetext{
${ }^{5}$ This was the case during the crisis. However, the more recently established governmentowned AMC can purchase assets from open banks.
} 
of bad loans as the rest of the surviving industry. This was the compromise adopted by Sweden. ${ }^{6}$ However, the structure of the banking sector also matters. For example, in countries where the assisted banks have relatively small market share the amount of loans purchased may not be an issue. In addition, in open bank assistance, it should be made clear that the purchase is a one-time deal, not to be repeated. An open-ended transfer arrangement could create moral hazard problems, undermining the credit discipline of the banks.

When handling all of the assets of failed banks, it is important to differentiate between the better quality loans and the impaired assets. Unimpaired performing loans will retain their value if left in the banking system and, consequently, should be transferred to other operating banks as quickly as possible. In the United States, the FDIC typically transfers the good loans to an assuming bank at the time of failure resolution. In Korea this was done through bridge banks, while in Thailand the assets of the closed finance companies were sold through public auctions.

If public AMCs have discretion in the choice of assets to purchase or take over, they should apply strict criteria in the selection of the assets. In principle, they should only take on those assets they are likely to manage more effectively. For example, fixed assets such as foreclosed properties and loans that require foreclosure or settlement with debtors are good candidates for transfer to AMCs. On the other hand, loans with potential for restructuring and those whose obligors are customers with whom the banks would like to maintain long-term relationships should be kept within the banks. Also, small credits whose recovery can be

\footnotetext{
${ }^{6}$ See Ingves and Lind (1997).
} 
undertaken more efficiently by the bank branches where the credit originated should also be left with the banks. Danaharta in Malaysia, for example, applies a minimum threshold of RM 5 million (approximately $\$ 1.5$ million) to the loans it will purchase. All banks are eligible to sell their impaired assets to Danaharta, but those with NPLs in excess of 10 percent of assets are strongly encouraged to reduce their NPL ratios.

\section{B. Pricing}

A realistic valuation/pricing of assets based on market pricing, sound accounting norms, strong loan classification and provisioning standards, and/or discounted present values, is crucial to the success of AMCs. The rigorous recognition of loan losses is the first and most important element of an effective strategy for dealing with problem assets, as it creates the right incentives for banks to restructure their loans, foreclose on collateral, and precipitate bankruptcy reorganizations.

The transfer of assets to AMCs, regardless of the methods of transfer, should be executed at fair market value. There are a number of reasons for doing so. First, private AMCs set up as subsidiaries of banks should not serve as a means by which the banks boost their capital by transferring their nonperforming assets at above market value to their $\mathrm{AMCs}{ }^{7}$

Second, AMCs should not serve as a means by which the government bails out private financial institutions by buying their nonperforming assets at above market value. Such a

\footnotetext{
${ }^{7}$ Consolidated supervision is necessary to prevent private financial institutions from using their AMC subsidiaries as a means to boost their capital positions artificially by transferring their assets to the AMCs at too high a price.
} 
transaction helps recapitalize the institution, which, in effect, conceals the cost of recapitalization from the public and violates the principle of transparency and accountability. In addition, when the purchase price is above market value, financial institutions may end up selling to AMCs too large a number of their nonperforming assets.

Third, transferring assets to government-owned AMCs at fair market value provides a clear goal for the management and staff of the AMC. If they can return some of the original equity capital in the AMC, they have done a good job, assuming that market prices do not move in unexpected directions.

While it is often difficult to price nonperforming assets (especially in the midst of financial crises), an approximation of their value, based on the probability of recovery, cash flow projections, and appraisal of collateral, should be carried out and used for the purpose of the transfer. When timing is an issue, and there are a great number of assets involved, the transfer can take place at an initial price with the explicit agreement that the final price of the transaction be established after the value of the assets has been estimated or the assets have been sold. The drawback of this approach is that it may reduce the willingness of the sellers to part with the assets since they will still maintain their exposure to the final price of the assets. In this situation, some form of profit-loss sharing arrangement can help partially overcome this problem. This has been the practice of Danaharta in Malaysia.

Danaharta purchased impaired loans at an average discount of 55 percent. Banks selling to Danaharta retain a right to receive 80 percent of any recoveries in excess of their acquisition cost the AMC is able to realize from the loans. While banks retain the option of keeping 
NPLs on their balance sheet rather than selling to Danaharta, if they do so they must make a provision that brings the value of the NPL down to 80 percent of the offer price. There have been some cases in which banks have rejected the Danaharta offer, believing themselves better able to effect recovery of the loan.

\section{Funding}

It is important that public AMCs are sufficiently funded in order to perform their intended functions. At the same time, they should also be subject to hard budget constraints. Striking the right balance is a key consideration of the funding process. To achieve transparency, the operating budget of the AMCs should be separate from its funding for asset takeover. If the AMC is set up as an ordinary corporation the structure of its balance sheet determines both its funding requirements and longevity.

Funding for government-owned AMCs often comes from the proceeds of either government bond issues or AMCs' own bond issues backed by the government, with the proviso that, whenever the AMCs realize losses, the losses be directly absorbed by the budget. Although the latter expedient is sometimes preferred because it is more transparent, it is important, in countries where the government bond market is small, that the bonds issued by the AMCs do not lead to segmentation in the secondary markets for government and government-backed bonds. To avoid that situation, bonds issued by the AMCs should carry the same characteristics as existing government bonds and any issues should be closely coordinated with other government bond issues. When the financing needs of the AMC are large, 
representatives of the AMC could usefully take part in the government debt management committee.

The bonds that are issued to fund the AMC should have maturities that are consistent with both the legal life of the $\mathrm{AMC}$ and reasonable expectations about the cash flow generation capabilities of the AMC. To a large extent these will be influenced by the types of assets the AMC hold and economic conditions. If the bonds are to be tradable, one issue that will need to be considered is their tax treatment. If the bonds are government guaranteed and pay the same rate as government securities, investors will review them on a tax equivalent basis, thus suggesting they be given the same tax treatment.

An example of good funding practices are those of KAMCO where tradable bonds, paying interest semiannually, are issued with a government guarantee. Danaharta's funding is in the form of five-year maturity zero coupon bonds that carry a central government guarantee. There is an active secondary market in these bonds. By contrast, the funding structure for the Bank Fund for the Protection of Savings (FOBRAPROA) in Mexico was not market based and was illiquid. The FOBRAPROA was funded by 10 -year promissory notes. Although these were backed by the government, they were not tradable instruments, and while interest accrued on the notes it was not payable until maturity.

\section{Asset Management and Disposition}

Strategies of asset management and disposition should be primarily a commercial decision and be guided by the goal of maximizing the value of assets by taking into account of market conditions as well as the funding cost of the AMCs. A number of countries established the 
goal of maximizing the recovery value on the transferred assets. A potential weakness in this approach is the lack of clarity with regard to the meaning of "recovery value." One interpretation is the maximization of the market value of the assets, regardless of the ultimate loss, and the other interpretation is the maximization of the book value of assets. The United States, when confronted with its savings and loan crisis, adopted by statute the goal of maximizing the net present value of the assets to be managed by the RTC and FDIC. This was an attempt to force the asset managers to recognize the time value of money in making decisions regarding the assets.

In Sweden, AMCs had to do the following calculation for each asset: if property prices are expected to climb gradually, what rate of yearly price increases are needed to compensate for the financial and other costs of holding onto the assets? If the required rate of increase is not judged to be realistic by property market experts, then the asset should be sold immediately. This simple method facilitated taking decisions leading to more rapid sales and also radically altered the time frame for the dismantling of the AMC.

There have been significant differences in the speed of disposition of assets among AMCs. Spain and the United States were relatively successful in disposing acquired assets rapidly. Similarly, Securum of Sweden disposed of 98 percent of its assets in the five years of its existence. By contrast, the fragile state of the Indonesian economy and the scale of the assets acquired by IBRA are among the factors that prevented the rapid disposition of assets in that country in early years. While IBRA did close down operations, in accordance with the sunset provision in the law, it transferred significant work to the ministry of finance. 


\section{Conclusions}

Proper management and disposition of nonperforming assets is one of the most critical and complex aspects of successful and speedy bank restructuring. The government's overarching objectives should be to maximize the value of the impaired assets in the system, while at the same time preventing credit discipline of borrowers from deteriorating. AMCs, with proper governance and incentive structures and sound operating strategies, could play an indispensable role in achieving the government's objectives.

In summary, this paper makes the following arguments:

- As part of the crisis management process, AMCs provide a useful vehicle for the authorities to remove nonperforming loans from the banking system quickly, so that the banking system can resume its normal functions, including providing payment services which are crucial to all economic activities, as soon as possible.

- $\quad$ Probably the most important purpose of having AMCs is the managerial factor. Management of impaired assets requires banks to have commercial skills different from those needed for lending. Banks may also have to become actively involved in the management of firms and properties, a task that in many cases banks have neither the expertise nor the resources to undertake.

- $\quad$ No single model of AMCs would fit all country circumstances. The optimal strategy could also vary over time. There are, however, common factors that contribute to the success of AMCs. These include supporting legal and regulatory environment, strong 
leadership, operational independence, appropriately structured incentives, and commercial orientation.

- $\quad$ AMCs should have a strict profit-maximizing goal. In all its operations, it should act as a normal market participant. This goal should guide all its operational policies, including the valuation of assets, funding strategy, and speed of asset disposition.

- A critical factor in assuring an AMC's success and independence is the ability of the public and the government to evaluate its performance. This requires proper accounting for the assets at the time of transfer and for cash flows over time. Performance should be measured against either a "mark-to-market" value or an estimated recovery value at the time of transfer. 


\section{REFERENCES}

Adams, Charles, Robert E. Litan, and Michael Pomerleano, eds., 2000, Managing Financial and Corporate Distress: Lessons from Asia, (Washington: Brookings Institution Press).

Enoch, Charles, Gillian Garcia, and V. Sundararajan, 1999, "Recapitalizing Banks with Public Funds: Selected Issues," IMF Working Paper 99/139, (Washington: International Monetary Fund)

Lindgren, Carl-Johan and others, 1999, Financial Sector Crisis and Restructuring: Lessons from Asia (Washington: International Monetary Fund)

Ingves, Stefan, and Goran Lind, 1997, "Loan Loss Recoveries and Debt Resolution Agencies: The Swedish Experiences," in Charles Enoch and John Green (eds.), Banking Soundness and Monetary Policy (Washington: International Monetary Fund)

Ingves, Stefan, and Dong He, 2000, "Facilitating Bank and Corporate Restructuring: The Role of Government," in Adams and others.

Klingebiel, Daniela, 2000, "The Use of Asset Management Companies in the Resolution of Banking Crises: Cross-Country Experience,” World Bank Policy Research Paper No. 2284 (Washington: World Bank)

Woo, David, 2000, “Two Approaches to Resolving Nonperforming Assets During Financial Crises,” IMF Working Paper 00/33 (Washington: International Monetary Fund) 